\title{
Criminality at Transport Facilities in Russian Federation: Situation, Tendencies, and Main Factors of the Development
}

\author{
Andrei Viktorovich Borisov \\ Law Institute of Russian University of Transport \\ Moscow, Russia \\ E-mail: av-borisov@mail.ru
}

\begin{abstract}
The situation and tendencies of the development of criminality on transport to a certain extent reflect events and processes occurring in branch and in society as a whole. The dynamics of recorded crimes committed at transport facilities demonstrate its qualitative transformation. The article describes transport criminality and identifies its main tendencies. The author also analyzes the factors determining crime at transport facilities and investigates key issues of law enforcement on transport. The study of indicators characterizing criminality at transport facilities in the Russian Federation in 2012-2018, as well as crime factors, led to the conclusion that modern crime prevention activity is narrowly focused and it is specialized mainly on countering traditional crimes, which does not meet modern criminal threats.
\end{abstract}

Keywords-criminal situation; criminality; crime situation; crime tendencies; transport; transport security; criminal threats; transport crime; law and order; crime factors; determination

\section{INTRODUCTION}

The transport complex of the Russian Federation, being one of the management branches, covers the defense needs, the industrial and agricultural production needs, trade and trade turnover, the population in transportation, serves as the material and technical basis for the territorial division of labour, has a significant impact on the dynamics and efficiency of the progressive development of some regions and the country as a whole [1]. In accordance with the current legislation, it includes objects and subjects of transport infrastructure, as well as vehicles [2].

The modern transport complex is not only a technical structure that solves the problem of moving goods from the sphere of production to the sphere of consumption, but also an actor of the "new product", providing a wide range of services to various entities [3]. In addition, it is included in the system of foreign economic, domestic political, environmental, anti-terrorist, information and scientific and technical security.

In this regard, the transport complex, on the one hand, is a source of increased danger and high-risk object [4], and on the other hand it is very vulnerable to external and internal threats (technical, technological, law enforcement (social) and natural), acts of unlawful interference into its activity, including criminal one.

Thus, the efficiency of the transport complex to perform its functions is directly dependent on the security level achieved on the highways, an important component of which is the law and order, which is a kind of security "measure" of public relations in the transport sector. At the same time, one of the main roles in ensuring transport security belongs to a set of measures of criminal-law and criminological nature. In this regard, information on the volume characteristics of crimes committed at transport facilities is very important, it makes it possible for law enforcement bodies and other subjects of prevention within their competence to determine priority areas of activity; optimize management decisions; in time, purposefully and effectively use measures to prevent and suppress offenses.

\section{The Position And Tendencies OF THE CRIME DEVELOPMENT AT TRANSPORT FACILITIES}

The analysis of official statistical data of the "Main information and analytical center of the Ministry of internal affairs of Russia" presents that the criminal situation at transport facilities still is rather intense [5], [6]. According to statistics, 38,605 crimes were registered in 2018, which is $0.1 \%$ lower than in 2017. Meanwhile, reduction of quantitative crime indicators does not allow to speak about the improvement of criminal situation at transport facilities, at least, for the following reasons:

- in comparison with 2016 and 2017 characterized with the significant consistent registered increase in crimes, the decrease in the analyzed value of the indicator is quite small (- 42 registered crimes);

- quality crime characteristics has negatively changed as against the background of the registered misdemeanor and felony crimes, there is registered an increase in minor and especially serious crimes (see "Table I"). There is the increase in corruption crimes [7], environmental crimes, as well as murders, crimes committed with the use of ammunition, firearms and gas weapons and in public places. 
affairs of Russia in North Caucasus Federal District (+2.0\%), the decrease in the East Siberian linear department of the Ministry of internal affairs of Russia on transport $(-3,4 \%)$, the Transport department of the Ministry of internal affairs of Russia in Siberian Federal District -3,8\%), the Transport Department of the Ministry of internal affairs of Russia in Volga Federal District (-6,0\%), the Transport Department of the Ministry of internal affairs of Russia in Northwest Federal District $(-6,1 \%)$, the Zabaykalsky linear department of the Ministry of internal affairs of Russia $(-10,2 \%)$.

In recent years there is the steady annual increase in the number of reported crimes on the service objects of the Transbaikalian linear department of the Ministry of internal affairs of Russia, the Transport Department of the Ministry of internal affairs of Russia in Central, Southern, NorthCaucasian and Ural Federal districts.

Theft is dominant in the structure of transport; crimes related to drug trafficking and weapons; crimes committed in public places; economic and corruption crimes; environmental crimes ("Table II"). internal affairs of Russia in the Far Eastern Federal District $(+3.3 \%)$, the Transport department of the Ministry of internal

TABLE II. N N Number OF CERTAIN TyPES OF REPORTEd CRIMES AT TRANSPORT FACILITIES OF THE RUSSIAN FEDERATION IN 2012-2018

\begin{tabular}{|c|c|c|c|c|c|c|c|}
\hline & 2012 & 2013 & 2014 & 2015 & 2016 & 2017 & 2018 \\
\hline $\begin{array}{l}\text { Murder and attempted } \\
\text { murder }\end{array}$ & 39 & 33 & 38 & 23 & 25 & 17 & 27 \\
\hline decrease/increase in \% & -25 & $-15,4$ & 15,2 & $-39,5$ & 8,7 & $-32,0$ & 58,8 \\
\hline $\begin{array}{l}\text { Intentional infliction of } \\
\text { serious bodily harm }\end{array}$ & 89 & 79 & 65 & 55 & 50 & 37 & 37 \\
\hline decrease/increase in \% & $-7,3$ & $-11,2$ & $-17,7$ & $-15,4$ & $-9,1$ & $-26,0$ & 0,0 \\
\hline Theft & 17133 & 14719 & 13772 & 14379 & 12126 & 12695 & 12649 \\
\hline decrease/increase in \% & 0,8 & $-14,1$ & $-6,4$ & 4,4 & $-15,7$ & 4,7 & $-0,4$ \\
\hline Robbery & 807 & 660 & 447 & 446 & 317 & 360 & 288 \\
\hline decrease/increase in \% & $-10,3$ & $-18,2$ & $-32,3$ & $-0,2$ & $-28,9$ & 13,6 & $-20,0$ \\
\hline Attack & 122 & 98 & 71 & 69 & 53 & 47 & 32 \\
\hline decrease/increase in \% & $-16,4$ & $-19,7$ & $-27,6$ & $-2,8$ & $-23,2$ & $-11,3$ & $-31,9$ \\
\hline Economic & 7603 & 6869 & 6358 & 6374 & 6261 & 5877 & 5702 \\
\hline decrease/increase in \% & $-47,6$ & $-9,7$ & $-7,4$ & 0,3 & $-1,8$ & $-6,1$ & $-3,0$ \\
\hline Corruption & 2218 & 2164 & 2203 & 2559 & 2912 & 2169 & 2456 \\
\hline decrease/increase in \% & - & $-2,4$ & 1,8 & 16,2 & 13,8 & $-25,5$ & 13,2 \\
\hline Ecological & 1038 & 1019 & 1144 & 1196 & 1260 & 1304 & 1405 \\
\hline decrease/increase in \% & $-12,7$ & $-1,8$ & 12,3 & 4,5 & 5,3 & 3,5 & 7,7 \\
\hline Terrorist & 13 & 10 & 7 & 3 & 1 & 4 & 2 \\
\hline decrease/increase in \% & 85,7 & $-23,1$ & -30 & $-57,1$ & $-66,7$ & 300,0 & $-50,0$ \\
\hline Extremist & 3 & 6 & 6 & 8 & 1 & 10 & 6 \\
\hline decrease/increase in \% & -50 & 100 & 0 & 33,3 & $-87,5$ & 900,0 & $-40,0$ \\
\hline $\begin{array}{ll}\begin{array}{l}\text { Drug } \\
\text { offences }\end{array} & \text { trafficking } \\
\end{array}$ & 11320 & 10939 & 11192 & 10440 & 10302 & 10821 & 9961 \\
\hline decrease/increase in \% & $-0,3$ & $-3,4$ & 2,3 & $-6,7$ & $-1,3$ & 5,0 & $-7,9$ \\
\hline $\begin{array}{l}\text { Crimes in the sphere of } \\
\text { illegal turnover of } \\
\text { weapons }\end{array}$ & 1817 & 1593 & 1453 & 1285 & 1165 & 1221 & 1180 \\
\hline decrease/increase in \% & $-17,8$ & $-12,3$ & $-8,8$ & $-11,6$ & $-9,3$ & 4,8 & $-3,4$ \\
\hline $\begin{array}{l}\text { Offences committed in } \\
\text { public places }\end{array}$ & 7658 & 8557 & 9296 & 9676 & 9271 & 9610 & 9714 \\
\hline decrease/increase in $\%$ & -5 & 11,7 & 8,6 & 4,1 & $-4,2$ & 3,7 & 1,1 \\
\hline
\end{tabular}

It should be noted that corruption and environmental crimes have a particularly high latency ratio (70-75), i.e. official statistics do not reflect the real situation with crime. This may indicate a possible decrease in the effectiveness of the criminal law influence on their prevention, as it is very problematic.
In 2018, there was the decrease in number of identified persons who committed crimes at transport facilities, -21351 $(-3.7 \%)$, the decrease of which is observed since 2016 ("Fig. $1 ")$. 


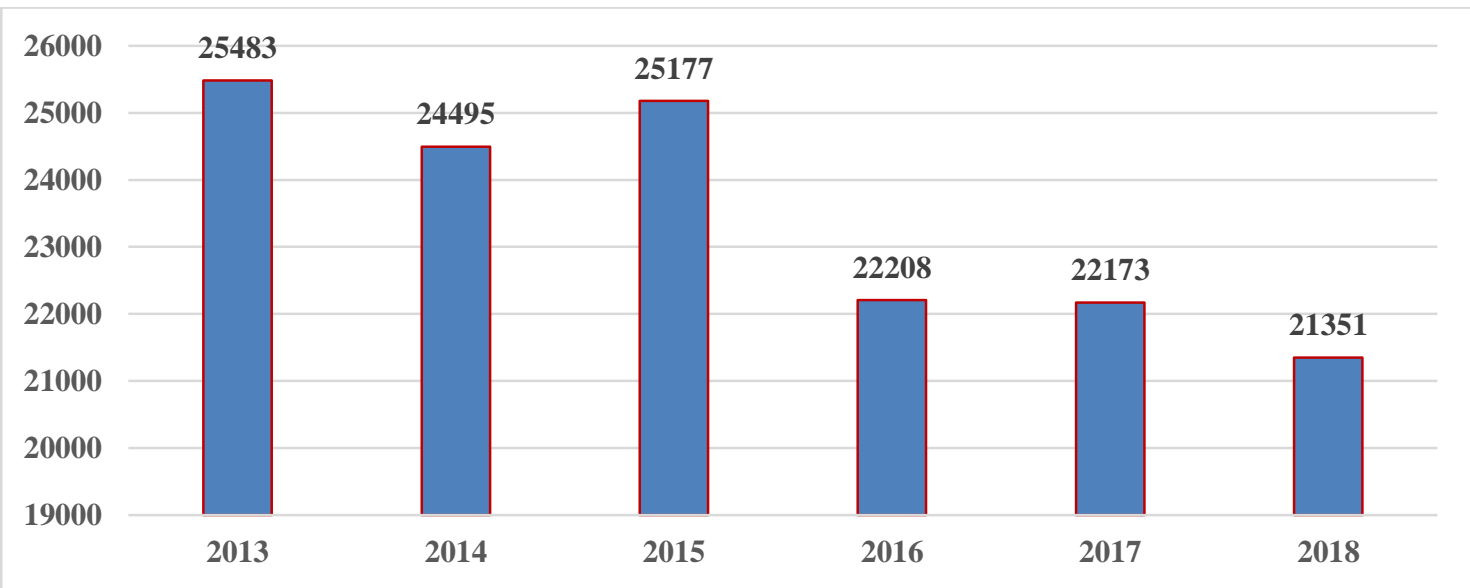

Fig. 1. Number of identified persons who committed crimes at transport facilities of the Russian Federation (2013-2018).

The analysis of statistical data about persons identified for crimes at transport facilities presents also tendency of the decrease in number of the revealed minors, unemployed persons, persons committing crimes in a state of intoxication, and persons who committed crimes before ("Table III").

TABLE III. DYNAMICS OF THE NUMBER OF PERSONS IDENTIFIED FOR COMMITTING CRIMES AT TRANSPORT FACILITIES OF THE RUSSIAN FEDERATION IN $2012-2018$

\begin{tabular}{|l|l|l|l|l|l|l|l|}
\hline & $\mathbf{2 0 1 2}$ & $\mathbf{2 0 1 3}$ & $\mathbf{2 0 1 4}$ & $\mathbf{2 0 1 5}$ & $\mathbf{2 0 1 6}$ & $\mathbf{2 0 1 7}$ & $\mathbf{2 0 1 8}$ \\
\hline $\begin{array}{l}\text { Persons who have committed crimes under the } \\
\text { influence of drugs }\end{array}$ & 1306 & 1639 & 1941 & 2278 & 2426 & 1916 & 875 \\
\hline $\begin{array}{l}\text { Persons who have committed crimes while } \\
\text { intoxicated }\end{array}$ & 2829 & 3300 & 3040 & 3082 & 2768 & 2681 & 2392 \\
\hline Pupils and students & 896 & 930 & 750 & 697 & 538 & 510 & 481 \\
\hline Persons without a permanent income & 16906 & 15772 & 14640 & 15214 & 12627 & 13006 & 12078 \\
\hline Unemployed persons & 3954 & 1492 & 1422 & 1400 & 590 & 209 & 72 \\
\hline Persons committed crimes before & 8798 & 9379 & 9749 & 10381 & 9977 & 10146 & 9543 \\
\hline Persons convicted before & 7998 & 7718 & 7199 & 6653 & 5585 & 5393 & 4790 \\
\hline Women & 2447 & 2030 & 2086 & 2312 & 2047 & 2012 & 2149 \\
\hline Minors & 830 & 724 & 519 & 419 & 343 & 266 & 224 \\
\hline
\end{tabular}

Thus, results of the criminal situation study on transport make it possible to identify its main trends in 2018:

- the significant reduction in reported misdemeanor and serious crimes, the significant increase in minor offenses and especially grave crimes;

- the increase in number of registered murders, crimes committed with the use of ammunition, firearms and gas weapons, corruption crimes and crimes committed in public places.

\section{TRANSPORT CRIME FACTORS}

Transport crimes are the result of a complex set of factors that determine them, which include direct sources of criminal threats and their criminogenic determinants, both common to all types of transport and specific to each of them, as well as characteristic of those crimes that are committed in this field. All these elements are not completely independent, but are subordinated as a relation of more to less, a structural part to a common system or an unsystematic part. They are a set of interrelated criminal phenomena and processes that can provoke, make conditions and contribute to harming the transport security of the Russian Federation and the environment, life and health of people, cause material damage, reduce the level of stability and comfort of the transport infrastructure use.

We refer to the direct sources of transport security criminal threats:

- Illegal actions:

Citizens (offenders, criminals, terrorists, pirates);

Officials (transport sector, supervisory and law enforcement bodies), as well as competitor organizations operating in the field of transport services;

Representatives of special services.

- Technogenic accidents (technical failures, accidents, fires, disasters), natural hazards (floods, earthquakes, hurricanes, landslides, etc.) and emergency situations, during which, as well as in the process of eliminating their negative consequences, there are favorable 
operations; short stay of goods and passengers at stations, airports and ports, as well as extensive opportunities for the use in criminal interests. These conditions form organizational and legal determinants associated with the organization of transport security subjects:

- The widespread use of standard actions and management decisions by the subjects of transport security is not always effective in rapidly, often unexpectedly, changing conditions. Certain actions enshrined in legal acts, brought to automatism, used for the implementation of transport security measures are certainly necessary and justified. However, the dynamics of the transport complex development, including in the field of law enforcement, causes new relations that are not regulated by normative legal acts [9]. Their legal regulation requires the operational improvement. The objective delay in this matter and omissions in some aspects give rise to disagreements and contradictions, often with criminal nature;

- To date, the basis for the adoption of coordinated decisions in the field of law enforcement by legislatively defined quite numerous transport security subjects have not been determined [10].

- So, for example, on railway transport such decisions besides law enforcement bodies can be made by paramilitary protection of railway transport and departmental auditor's office in the sphere of passenger transportations [11];

- A large number of issues on the interaction organization in the direct implementation of security measures at transport facilities are regulated by departmental and local regulations, often duplicating or competing with each other on significant positions, generating disagreements of subjects;

- Defects in the traffic organization, leading to abnormal situations that facilitate committing crimes;

- The decrease in the level of the police activity on transport, in connection with reforming the law enforcement sector, "substitute" employees of internal affairs bodies by technical means of control, as well as the staff shortage of the internal affairs bodies on transport, due to the increase in the load on the stuff. This problem becomes especially acute in an emergency situation;

- Cases of violations of labour and industrial discipline by transport workers (absenteeism, late arrival at work, drinking alcohol during working hours, etc.), as well as the use of their official position for personal purposes.

Another significant block of a criminogenic determinants of information are information ones. Communication and digital technologies are increasingly being introduced into society. 
- a significant number of thefts committed at transport facilities and not registered by the internal affairs bodies. There are two reasons for this: first, the most common is the opinion of victims about the meaninglessness and cost of filing a statement about the incident.

Secondly, this may be due to the fact that arriving at the destination, the main part of passengers due to emotional and physical position does not check their luggage at the railway station, at the airport, etc. (i.e. in the territory of operational service of internal affairs bodies in transport).

As a rule, passengers detect the loss at home or at place of stay, after a certain period of time. If the statement about the incident is submitted to the internal affairs bodies, it is in accordance with the part 2 of the article 152 of the Code of Criminal Procedure (the preliminary investigation place) at the place of residence or stay of the victim, i.e. the place of the crime detection or its consequences. Thus, the crime committed at the transport facility is not taken into account, its causes and conditions are not identified and eliminated, keeping the criminality of the situation.

Determinants related to the victimization of injured persons due to crimes committed at transport facilities are significant. Such determinants are most frequent in property crimes. Here victimization of injured persons is due to inattention, credulity, frivolity, imprudence, uncriticism, alcoholic intoxication, which occurred as a result of drinking alcohol with unfamiliar people, the excessive frankness, manifestation of gambling as a character trait, and other immoral, provoking and aggressive behaviour.

This type of determination should include the lack of awareness of citizens about the ways of committing crimes on transport, since the information work in this area of prevention is fragmentary.

A key element of the transport complex functioning is a person who manages vehicles or maintains them and transport infrastructure. The actions and behaviour of other participants in public relations arising in the transport sector are also important. The degree of transport security from criminal attacks (psychological determinants) depends on their personal qualities, qualification, skills, health, level of legal consciousness (everyday, professional, scientific) and legal culture.

The practical aspect of legal consciousness is realized in the behavioural function of the individual, his/her will in processing and reproducing legal beliefs, affecting the mechanism of mental regulation of behaviour. Sometimes in the process of social interaction, there are its deformations. The deformation of legal consciousness of public relations participants in the transport sector is a social phenomenon that carries the denial of the ideas of law that are important for transport security.

The degree of deformation causes the creation of conditions for the formation and implementation of criminal intent (negligence) in the field of activity of the individual [13]. 
[13] Porublev, A.V. (2017). Interpretation Problems of the "Road Safety" concept. Bulletin of NCSTU. Vol. 2 (29). P. 122-125.
Thus, the analysis of official statistical data makes it possible to conclude that the activity of law enforcement bodies at the transport facilities of the Russian Federation to combat crime in recent years has contributed to the decrease in the absolute indicators of certain types of crimes, which reflects the positive trend of the current criminal situation.

At the same time, there is a noteworthy increase in certain types of crimes in 2018; new threats to law and order in transport, which not only complicates the criminal situation, but also predetermines the priority directions of preventive activity of law enforcement bodies, the need to take adequate and timely measures. Meanwhile, the legislator has not fully perceived such danger factors yet. Transport law enforcement policy is narrowly focused and it is specialized mainly on countering traditional crimes, the importance of which is not denied, but it should not exclude an adequate response to new threats.

\section{REFERENCES}

[1] Markelov, G.Ya., Pugachev, I.N., Saltanova, E.D. (2015). Factors of the Development of Intelligent Transport Systems. Transport of AsiaPacific Region, No. 1 (2,3). P. 42-46.

[2] Federal Law No. 16-FL from 09.02.2007 (as amended on 02.08.2019) "On transport security". In Collection of Legislation of the Russian Federation. 12.02.2007. No. 7. article 837.

[3] Dukhno, N.A. Law and Theoretical Problems of Security in the Transport Complex. Transport Law and Security, 11 (23). P. 9-25.

[4] Nazarkin, M.V. (2004). Safety of High-risk Facilities as a Component of National Security of the Russian Federation. In Place and Role of the MIA of Russia in Providing Special Legal Regimes: Collection of scientific works. Moscow: Institute of the Interior Ministry. P. 138153.

[5] Afanasyeva, O.R., Brazhnikov, D.A., Goncharova, M.V., Malikov, S.V., Shiyan, V.I. (2017). Copmplex Analysis of the Criminality Degree in the Russian Federation at the end of 2016 and the Expected Trends of its Development: Analytical Review. Moscow: FSKU "Institute of the Ministry of Internal Affairs of Russia", $54 \mathrm{p}$.

[6] Antonyan, V.M., Brazhnikov, D.A., Goncharova, M.V. et al. (2018). Copmplex Analysis of the Criminality Degree in the Russian Federation at the end of 2016 and the calculated Options of its Development: Analytical Review. Moscow: FSKU "Institute of the Ministry of Internal Affairs of Russia", $86 \mathrm{p}$.

[7] Afanasyeva, O.R., Shiyan, V.I. (2018). The Degree of Corruption Crimes at Transport Facilities. Bulletin of the Academy of Law and Management, 3 (52). P. 37-44.

[8] Murashov, P.I. (1971). Operational Situation: Content and Concept. Newsletter of the Department of Internal Affairs of the Leningrad Executive Committee. No. 19-20.

[9] Sosnovskaya, Yu.N., Markina, E.V. (2019). Problem Questions in Legal Regulation of law enforcement bodies activity on transport. Bulletin of Economic Security, No. 1. P. 193-196.

[10] Levchenko, O.P., Dorofeev, I.N. (2018). The Main Directions of the Development of Law Enforcement Bodies on Transport. Network Edition "Academic Thought", 3 (4), P. 52-55.

[11] Dorofeev, I.N., Pestov, N.N. (2017). Factors Causing Specificity of Activity of Law Enforcement Bodies in Transport in Modern Conditions. Proceedings of Academy of Management of the Ministry of Internal Affairs of Russia, 2 (42). P. 74-77.

[12] Kupriyanovsky, V.P., Namiot, D.E., Sinyagov, S.A. (2016). A CyberPhysical System as the Basis for the Digital Economy. International Journal of Open Information Technologies, 2. P. 18-25. 